\title{
Impact of the invasive species Vossia cuspidata (Roxb.) Griff. on the diversity and temporal changes of the native flora of the River Nile in Egypt
}

\author{
Waleed F. Mahmoud ${ }^{1}$; Emad A. Farahat ${ }^{2 *}$; Gamal M. Fahmy ${ }^{1}$; Hussein F. \\ Farrag $^{1}$; Hossam E.A. Awad ${ }^{1}$
}

${ }^{1}$ Botany and Microbiology Department, Faculty of Science, Cairo University, Egypt

${ }^{2}$ Botany and Microbiology Department, Faculty of Science, Helwan University, Egypt

*Corresponding author :emad23_1999@yahoo.com, ORCID ID: 0000-0003-3115-1912

\begin{abstract}
Invasive plant species are major drivers of biodiversity losses, particularly on islands that are vulnerable to invasion and extinction. The objective of this study was to document the vegetation structure and changes over time in two Nile Islands due to invasion by Vossia cuspidata (Hippo grass). One-hundred and one stands were assigned in three sites along the River Nile in Cairo, Egypt. Fifty-one associated species were recorded, belonging to 28 families. Annuals (Thereophytes) were the main life form in the area (51\%) followed by helophytes (29\%). Twelve vegetation groups were identified, representing the main communities in the studied stands. $V$. cuspidata was the dominant species and its maximum cover was recorded during the summer season. The lowest values for species diversity were recorded in open water, while the highest values were recorded in water edges and slopes of the riverbanks. There was up to $70 \%$ reduction in the cover of native species in the study area due to the invasion by $V$. cuspidata. Many native species were either disappeared or poorly recorded in the studied sites. Stem height and the cover of $V$. cuspidata in aquatic and riparian habitats lead to severe negative impacts on the growth and the diversity of native flora in the River Nile. Consequently, conservation of the native flora through removing the invasive species should be a future priority along the River ecosystem.
\end{abstract}

Keywords: Hippo grass; Phytosociology; Invasive plants; Native species; River Nile.

\section{Introduction}

Biological invasions by non-native species have become a major environmental problem and a focus of ecological research (Seebens et al. 2015; van Kleunen et al. 2015; Seebens et al. 2017). A plant invader is a species that transported accidentally or deliberately by man, which once arrived at a new region can establish a self-sustained population and spread at a faster rate from the introduction point (Richardson et al. 2000; Blackburn et al. 2011). Most of the invaders are not cosmopolitan, while several cosmopolitans have not developed invasion behavior (Hegazy et al. 1999).

Habitats become susceptible to invasion in rich environments, presence of disturbance and competition that facilitate the successful establishment and colonization of invasive species (Smith and Knapp 1999;
Koerner et al. 2015; Tognetti and Chaneton 2015). Due to the interaction among these factors, habitat disturbance with high resource availability may enhance the invasion process. Several studies assessed the ecological impacts of the invasive species in the area of introduction by comparing species fitness, community structure or ecosystem processes between invaded and reference non-invaded sites (e.g., Pyšek et al. 2012; Castro- Díaz et al. 2014; Kumschick et al. 2015). One of the most widely used indicators of the ecological impact is native species richness or diversity, which tends to decrease in invaded sites (Vilá et al. 2011). The impact of an invasive species on an ecosystem depends on how the function of this new species is in the invaded community (Thuiller et al. 2010; Castro-Díaz et al. 2014). Therefore, some alterations and 
loss of biodiversity may occur because of functional competition of the invasive species that suppresses native species populations and alters habitats and ecosystems (Galatowitsch 1999; Pfisterer 2004).

Time since the invasion is an important factor that affects the extent of the impact of the invaded species on the community level and changes in the abundance of alien and native species (Strayer et al. 2006, Dostál et al. 2013).

Vossia cuspidata (Roxb.) Griff. (Hippo grass) is a perennial aquatic grass belongs to the Poaceae family (Boulos 2005). It is mostly distributed in the rainforest areas of the world such as Southeast Asia and Tropical Africa (Raphael et al. 2016). In Egypt, this species is a new invasive plant to the aquatic and riparian habitats and recorded in many sites in Cairo and Nile Delta (Shehata 1996; Galal et al. 2017). The species had not been included in any Egyptian Flora or checklist before Boulos (1995). It reproduces only by rhizomes and spreads horizontally either on the water surface or on the banks of the watercourse (Shehata 1996). V. cuspidata can resist drought, high $\mathrm{pH}$, loamy soil, and waterlogged areas (Raphael 2016). It reaches a height of $3 \mathrm{~m}$ above the water surface.

Studying the negative impacts of the invasive plant species on resident vegetation communities is an important step in understanding the changes in the diversity of native species and its subsequent impacts on the ecosystem. Therefore, the main objective study was to document the vegetation structure and changes over time in two Nile Islands due to their invasion by $V$. cuspidata.

\section{Materials and Methods Study area:}

The study area located in the southern section of the Nile Delta in Greater Cairo, and it covered three sites in Giza Governorate between latitude $30^{\circ} 06^{\prime} 43.47^{\prime \prime}$ to $29^{0} 58^{\prime}$ $45.31^{\prime \prime} \mathrm{N}$ and longitude $31^{\circ} 13^{\prime} 12.41^{\prime \prime}$ to $31^{\circ}$ 13' 16.30" E (Fig. 1). It includes sites in two Nile Islands (Bin El-Bahrin Island and Warraq Island) and one location at Northern Cairo called Qanater. The study area belongs to the Nile phytogeographical region in Egypt.

Geomorphologically, there were four main habitats or microsites in each visited site of the study area along the River Nile banks: terrace, slope, water edge and open water. Terraces are defined as the dry upper part of the water bank; slopes are the declining part of the ground from terraces to water edges that extend from 1 to $3 \mathrm{~m}$ away from water edges at maximum. The water edge is the part of the bank in contact with water. The sampled open water sites are away from the shoreline by 10 to $20 \mathrm{~m}$. In the study area, the maximum summer air temperature was $33.3^{\circ} \mathrm{C}$ in June and the minimum winter air temperature was $6.2^{\circ} \mathrm{C}$ in February (courtesy of the Egyptian Meteorological Organization, 2020). Relative humidity ranged from $73.7 \%$ in November to $58 \%$ in May. The maximum solar radiation

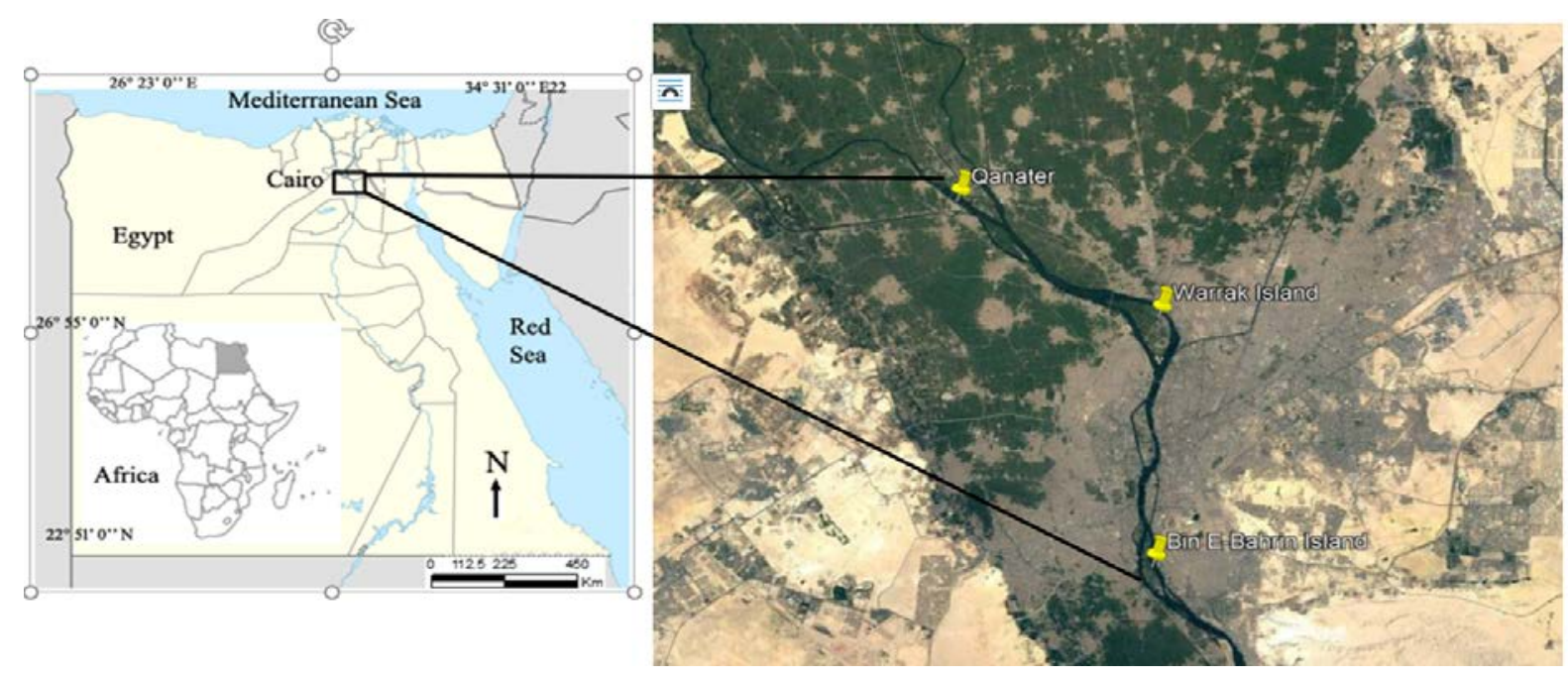

Fig. 1. Location map of the study area showing the three studied sites for V. cuspidate in Greater Cairo, Egypt. 


\section{Impact of the invasive species Vossia cuspidata}

minimum is in January (9 $\left.\mathrm{MJ} \mathrm{m}^{-2} \cdot \mathrm{day}^{-1}\right)$. The mean maximum wind speed is $3 \mathrm{~m} / \mathrm{s}$ in April, May and June and the mean minimum is 1.7 $\mathrm{m} / \mathrm{s}$ in November. The total annual precipitation over Cairo does not exceed 60 $\mathrm{mm} /$ year.

\section{Vegetation sampling and procedures}

One-hundred and one stand (20 $\mathrm{m}^{2}$ each) were assigned in the study area to cover the different habitats of $V$. cuspidata: 16 in terraces, 19 in slopes, 39 in water edges, and 27 in open water. There were 36 sites at Bin El-Bahrin Island, 38 sites at Warraq Island, and 27 sites at Qanater. The stands were randomly chosen whenever considerable vegetation cover was encountered including $V$. cuspidata. Due to the intensive invasion of $V$. cuspidata in the study area, it was difficult to divide the sampled stands as invaded and non-invaded stands. The stands were sampled during the four seasons of the year, from February 2017 to January 2018. Using the modified Braun-Blanquet cover/abundance scale, the presence of all species with their percentage cover was recorded in each stand (Braun-Blanquet, 1964). As well, the life forms, families and geographical distribution of the recorded species were determined according to BraunBlanquet (1964). The collected plant species were identified according to Täckholm (1974) and Boulos (1995, 1999 and 2000) at the herbarium of Botany Department, Faculty of Science, Cairo University.

\section{Soil and water sampling}

Three soil samples were collected from the soil profile at $0-30 \mathrm{~cm}$ from the soil surface at each stand in terraces and slopes, then they were mixed as one composite sample for each stand. Each air dried and sieved soil sample was analyzed chemically and physically, and the following assays were carried out: electrical conductivity (EC) was determined in the soil paste extract using electrical conductivity meter and $\mathrm{pH}$ values by $\mathrm{pH}$ meter in 1:2.5 soil-water suspension (Chapman and Pratt 1961). Sodium (Na), potassium (K), calcium (Ca) and magnesium (Mg) were determined by using Microwave Plasma Emission spectrometer (MPE-4200, Agilent co.), chloride (Cl) by titration against $\mathrm{AgNO}_{3}$, carbonate and bicarbonate by titration against $\mathrm{HCl}$ and sulphate was calculated by difference between anions and cations (Allen et al. 1990). Organic matter content was determined according to Walkley and Black method, (Black 1982). Soil available nitrogen was measured by using $50 \mathrm{ml} \mathrm{KCl}(2 \mathrm{~N})$ as an extractable solution for $5 \mathrm{gm}$ soil, then the available $\mathrm{N}-\mathrm{NH}_{4}+$ and $\mathrm{N}-\mathrm{NO}_{3}$ - in the filtrate were determined by Technician Auto Analyzer according to (Markus et al. 1982). Soil texture was determined by the hydrometer method (Allen et al. 1990).

Water samples were collected from the stands of the open water and water edge habitats, which were collected from three stands covering the area of a certain site, then mixed as one composite sample for each stand. Each sample was taken from the top down to $50 \mathrm{~cm}$ depth from the water surface. Measurements of $\mathrm{pH}, \mathrm{EC}$ and dissolved oxygen were carried out directly after collection. The collected samples were subjected to the following measurements: soluble $\mathrm{N}-\mathrm{NH}_{4}{ }^{+}$and $\mathrm{N}-\mathrm{NO}_{3}{ }^{-}$were determined as mentioned for soil samples, (Markus et al. 1982). Concentration of dissolved oxygen in water samples (as ppm) was measured using a glass electrode meter. Water reaction $(\mathrm{pH})$, sodium, potassium, calcium, magnesium, chloride, carbonate, bicarbonate, and sulphate were estimated using the above-mentioned methods in soil analysis (Allen et al. 1990). Water and sediment samples were subjected to ANOVA-1 analysis to estimate the variations in the analyzed elements the identified vegetation groups.

\section{Vegetation classification and Community ordination}

The cover estimates of 51 species were recorded in 101 stands and were subjected to multivariate analysis. Two-way indicator species analysis (TWINSPAN) was performed to classify the vegetation in the study area (Hill 1979a, b) using Community Analysis Package (CAP ver. 1.2., PICES Ltd., UK). TWINSPAN classifies the sampled stands and the recorded 


\section{Waleed F. Mahmoud et al.}

species according to their ecological preferences. The resulting vegetation groups (plant communities) were named after the dominant species that had the highest presence percentages in the stands of each group. Detrended correspondence analysis (DCA, Hill 1979a, b) was conducted by applying the default options of DCA in the PC-ORD 5.06 (MjM Software, OR, USA) to check the magnitude of change in species composition along the first ordination axis (i.e., gradient length in standard deviation units, SD). It was found that DCA $=4.12$ SD units. Consequently, the relationships between vegetation gradients and the measured environmental variables were demonstrated on the ordination biplot produced by corresponding canonical analysis (CCA, Leps and Šmilauer, 2003). A Monte Carlo permutation test (499 permutations; Ter Braak and Smilauer, 2002) was utilized to test the significance of the eigenvalues of the first canonical axis. Intraset correlations from the CCA were used to evaluate the importance of the environmental variables. The vegetation groups that resulted from cluster analysis were subjected to ANOVA based on the environmental variables. DCA and CCA were used as complementary analyses for better understanding of the plant community distribution.

\section{Species diversity pattern}

Species richness (alpha-diversity) was calculated for each vegetation group as the average number of species per stand. Species turnover (beta-diversity) was calculated as the ratio between the total number of recorded species in a certain vegetation group and its alpha-diversity (Whittaker 1972). The Shannon-Wiener index for the relative evenness and Simpson's index of diversity (D) were calculated for each stand based on the mean cover of the species (Pielou 1975; Magurran 1988). The analysis was carried out by using Species Diversity and Richness software (SDR ver. 2.3, PICES Ltd., UK).

\section{Temporal variations in native species composition}

To assess the impact of invasion on species composition and relative covers of native species in our study area, we calculated the Sørensen index of similarity and correlation coefficients between each location stands. This was based on two different censuses at the same sites during 2003 (Galal 2001; Farahat 2006) and 2017 (the present study). The temporal changes in the dominance of the most common native species at the same sites were plotted in comparison to $V$. cuspidata. It worth noting that the sampling design in our study and the previous ones (Galal 2001; Farahat 2006) were similar. V. cuspidata was recorded by the two previous studies but in few sites and low cover.

\section{Results}

\section{Floristic composition and structure}

Fifty-one species belong to 28 families were recorded in the studied area (Appendix 1). The most species-rich families were Poaceae (8 species), Astraceae (6 species), Polygonaceae (5 species), followed by Solanaceae (3 species), while there were two species in the families Chenopodiaceae, Brassicaceae, Cyperaceae, Euphorbiaceae and Fabaceae. Four of the recorded species are ubiquitous (have a wide ecological range of distribution), viz. V. cuspidata, Eichhornia crassipes, Ludwegia stolonifera, and Phragmites australis with the highest presence values (35$100 \%)$. Fig. 2A shows that most of the recorded species were annuals i.e., therophytes (51\% of the total recorded species) and helophytes (29\%). Nano-phanerophytes and chaemopytes were $6 \%$ (3 species for each), while geophytes and hemicryptophytes were represented by two species for each. The geographical distribution of the recorded species (Fig. 2B) shows that 38 species (75\% of the total recorded species) were monoregional; of which 14 species (27\%) were native to the cosmopolitan chorotype. Pantropical ranked second with $20 \%$. About $25 \%$ of the recorded species are bi-regional and pluri-regional, extending their distribution all over the Mediterranean, Irano-Turanian, Euro-Siberian, Saharo-Sindian and SudanoZambezian regions. 


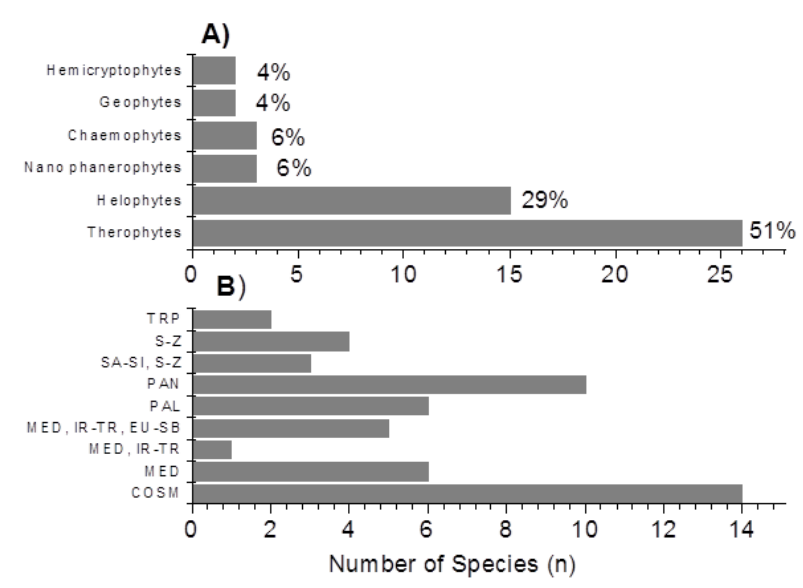

Fig. 2. Life forms (A) and geographical distribution (B) of the recorded associated species with Vossia cuspidata in the study area along the River Nile, Cairo. COSM = Cosmopolitan, PAL = Palaeotropical, PAN = Pantropical, S-Z = SudanoZambezian, $\mathrm{MED}=$ Mediterranean, SA-SI $=$ Saharo-Sindian, TRP $=$ Tropical, IR-TR = IranoTuranian, EU-SB = Euro-Siberian. A = Annual, Th $=$ Therophytes, Hy = Hydrophytes, $\mathrm{H}=$ Hemicryptophytes, N. Ph = Nano phanerophytes, Ch $=$ Chaemophytes, $\mathrm{G}=$ Geophytes.

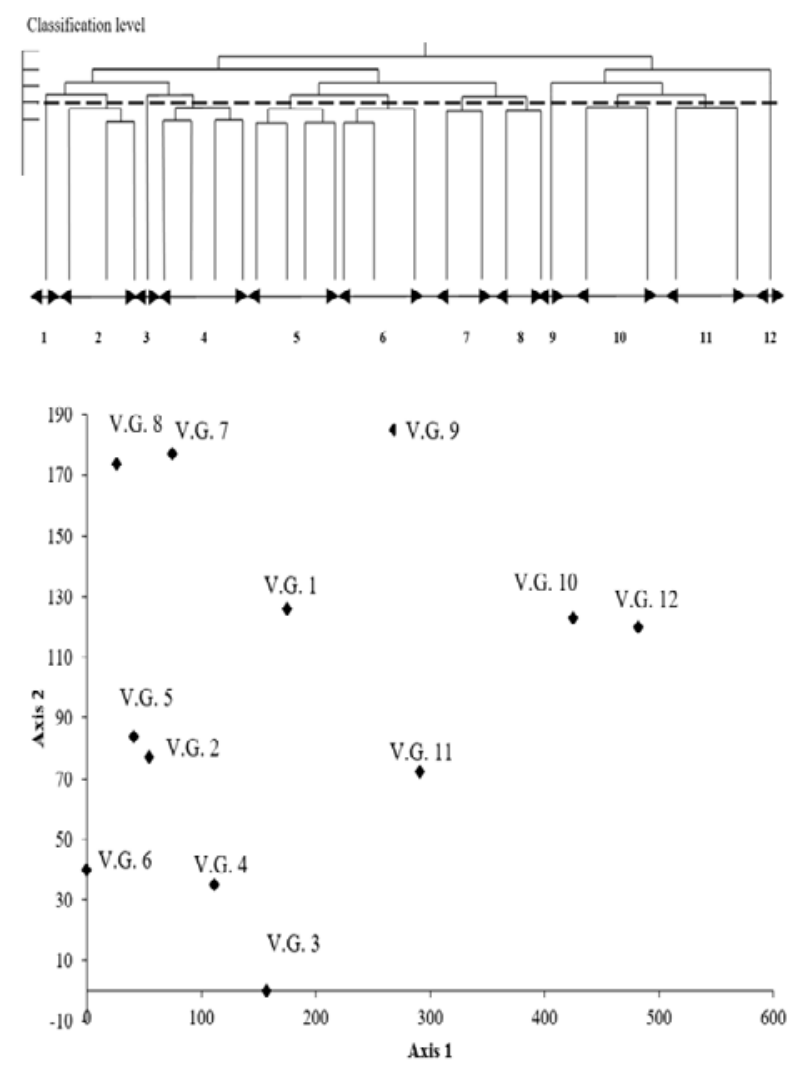

Fig. 3. The generated vegetation groups by application of TWINSPAN on the presence/absence matrix of the recorded associated species in the sampled 101 sites (upper) and detrending corresponding analysis (DCA) on the produced vegetation groups (lower).

\section{Vegetation classification and main plant communities}

Based on the distribution of species in the different habitats and the presence of indicator species, we found that the $4^{\text {th }}$ level of the TWINSPAN division was informative in defining the number of plant communities (Fig. 3). Twelve plant communities (groups) were identified. The twelve plant communities were Persicaria senegalensis- Phragmites australis, V. cuspidata- Ipomea carnea, P. australis- V. cuspidata (VG. 3), P. australisIpomea carnea (VG. 4), V. cuspidataLuwdegia stolonifera, $V$. cuspidataCeratophyllum demersum, V. cuspidata- P. senegalensis, $V$. cuspidata- Eichhornia crassipes, Cynodon dactylon- V. cuspidata, Rumex dentatus- C. dactylon, $C$. dactylon- $P$. australis, Bidens pilosa- Apium leptophyllum. These communities were named after the first and occasionally the second dominant species that had the highest percentage and the highest relative cover. The DCA analysis indicates a clear segregation for the vegetation groups along axes 1 and 2 (Fig. 3). The twelve TWINSPAN groups were separated along the first (eigenvalue $=0.82$ ) and second (eigenvalue $=0.26$ ) DCA axes. Higher eigenvalues of the first DCA axis indicated that it captured the greater proportion of the variation in the species composition among stands. The two DCA axes explained $23.6 \%$ and $31.1 \%$ of the total variation in the species data, respectively. The lengths of the gradients were: 4.83 for the first axis, and 1.86 for the second. The stands of vegetation groups (VG) 2, 4, 5, 6, 7 and 8 were separated toward the negative end of DCA axis 1, while stands of VG 10 and 12 were separated out along the other end, and those of group VG 1, 3, 9 and 11 were transitional in their composition between the other groups.

The following is a brief description of these vegetation groups (Table 1): the vegetation was distributed in different habitats with three groups (VG 1, 3 \& 12) inhabiting only terraces. The water edges were mainly inhabited by 6 vegetation groups (VG 2, 4, 5, $8,9 \& 10$ ), while water habitat was mainly inhabited by VG 6 . The other vegetation groups were mixed and represent more than two habitats. Each plant community was identified by the plant species that showed the highest presence and cover percentages. 
Table (1): Characteristics of the 12 vegetation groups (derived at level 4) after the application of TWINSPAN on the 101 sampled stands of the study area. N: number of the stands, G/P: ratio of the stands representing each vegetation group to the total sample stands (\%), T: terraces, S: slopes, WE: water edge, W: open water, P: presence percentage (\%), Co: mean cover (\%).

\begin{tabular}{|c|c|c|c|c|c|c|c|c|c|c|c|c|}
\hline \multirow{2}{*}{$\begin{array}{l}\text { V. } \\
\text { G. }\end{array}$} & \multirow{2}{*}{$\mathrm{N}$} & \multirow{2}{*}{$\mathrm{G} / \mathrm{P}$} & \multicolumn{4}{|c|}{ Habitat } & \multirow{2}{*}{$\begin{array}{l}1^{\text {st }} \text { dominant } \\
\text { species }\end{array}$} & \multirow{2}{*}{$\mathrm{P}$} & \multirow{2}{*}{ Co } & \multirow{2}{*}{$2^{\text {nd }}$ dominant species } & \multirow{2}{*}{$\mathrm{P}$} & \multirow{2}{*}{ Co } \\
\hline & & & $\mathrm{T}$ & $\mathrm{S}$ & WE & $\mathrm{W}$ & & & & & & \\
\hline 1 & 1 & 0.01 & 100 & - & - & - & $\begin{array}{r}\text { Persicaria } \\
\text { senegalensis } \\
\text { (Meisn.) Soják }\end{array}$ & 100 & 15 & Phragmites australis & 100 & 15 \\
\hline 2 & 7 & 0.07 & 42.9 & 14.3 & 42.9 & - & $\begin{array}{r}\text { Vossia cuspidata } \\
\text { Phragmites }\end{array}$ & 100 & 56.1 & Ipomea carnea Jacq. & 100 & 14 \\
\hline 3 & 2 & 0.02 & 100 & - & - & - & $\begin{array}{l}\text { australis (Cav.) } \\
\text { ex Steud. Trin. }\end{array}$ & 100 & 40 & Ipomea carnea Jacq. & 100 & 5.0 \\
\hline 4 & 12 & 0.12 & 16.7 & 25 & 50 & 8.33 & $\begin{array}{r}\text { Phragmites } \\
\text { australis }\end{array}$ & 100 & 33.9 & Vossia cuspidata & 91.7 & 13.7 \\
\hline 5 & 40 & 0.40 & 7.5 & 15 & 45 & 32.5 & Vossia cuspidata & 100 & 66.7 & $\begin{array}{r}\text { Ludwigia stolonifera (Guill. \& } \\
\text { Perr.) Raven }\end{array}$ & 35 & 2.5 \\
\hline 6 & 13 & 0.13 & - & - & 15.4 & 84.6 & Vossia cuspidata & 100 & 43.5 & Ceratophyllum demersum L. & 100 & 13.4 \\
\hline 7 & 5 & 0.05 & - & 80 & 20 & - & Vossia cuspidata & 100 & 35.6 & $\begin{array}{r}\text { Persicaria senegalensis } \\
\text { Eichhornia crassipes (Mart.) }\end{array}$ & 100 & 28.7 \\
\hline 9 & 2 & 0.02 & - & - & 100 & - & $\begin{array}{l}\text { Cynodon dactylon } \\
\text { (L.) Pers. }\end{array}$ & 50 & 8.8 & Vossia cuspidata & 100 & 3.9 \\
\hline 10 & 5 & 0.05 & - & 40 & 60 & - & $\begin{array}{r}\text { Rumex dentatus } \\
\mathrm{L} .\end{array}$ & 100 & 10.4 & Cynodon dactylon & 80 & 4.9 \\
\hline 11 & 6 & 0.06 & 33.3 & 50 & 16.7 & - & Cynodon dactylon & 100 & 10.6 & $\begin{array}{r}\text { Phragmites australis } \\
\text { Apium leptophyllum F. Muell \& }\end{array}$ & 50 & 7.6 \\
\hline 12 & 3 & 0.03 & 100 & - & - & - & Bidens Pilosa L. & 66.7 & 11.7 & Benth. & 33.3 & 8.3 \\
\hline
\end{tabular}

\section{Species diversity}

The seasonal variations in the mean cover percentages of $V$. cuspidata at different studied habitats is shown in Fig. 4. The highest mean cover\% of $V$. cuspidata in the studied habitats was recorded in summer, followed by autumn (except in terraces), with a mean cover of $53.5 \%$ (Fig. 4). The generated vegetation communities (groups) of the species in the study area showed variable diversity indices (Table 2). For instance, the Bidens pilosa- A. leptophyllum group (VG.12) had the highest value of species richness (11 sp./stand), while VG.4 had the lowest value of species richness (3.17 sp./stand) and the highest value of species turnover (Table 2). In contrast VG. 9 had the lowest value of species turnover (0.7). Generally, species richness was higher for vegetation groups 9, 10, 11 and 12, (10.0, 9.2, 9.17 and $11.0 \mathrm{sp.}$ /stand, respectively) compared with the vegetation groups $2,4,5$ and 6 (3.43, 3.17, 3.25 and 3.92 sp./stand, respectively). Shannon index varied significantly among vegetation groups which ranged from 1.68 in vegetation group 10 to 1.8 in vegetation group 11 .
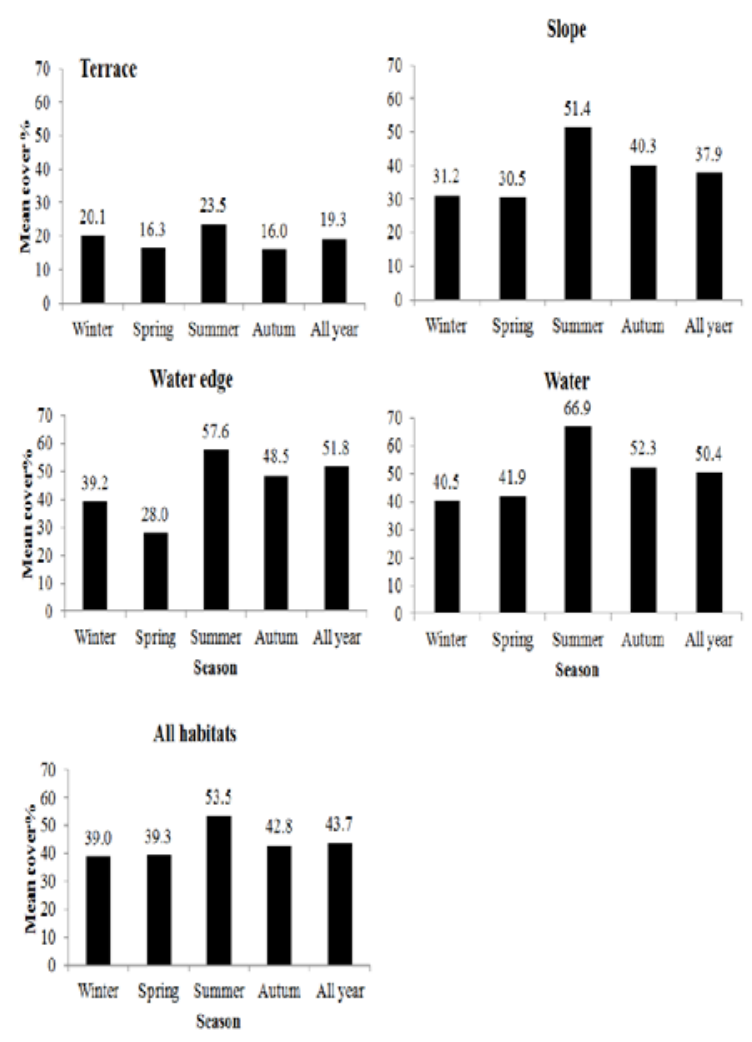

Fig. 4. Seasonal variations in the mean cover \% of Vossia cuspidata at different studied habitats in the study area. 
Table (2): Variations in some diversity indices calculated for the 12 vegetation groups derived after application of TWINSPAN on the 101 stands of the study area.

\begin{tabular}{cccccc}
\hline VG & $\begin{array}{c}\text { No. of } \\
\text { Stands }\end{array}$ & $\begin{array}{c}\text { Shannon } \\
\text { Index } \\
\text { (Relative } \\
\text { evenness) }\end{array}$ & $\begin{array}{c}\text { Simpson } \\
\text { D }\end{array}$ & $\begin{array}{c}\text { Species } \\
\text { richness }\end{array}$ & $\begin{array}{c}\text { Species } \\
\text { turnover }\end{array}$ \\
\hline VG1 & 1 & 1.55 & 4.87 & 5.00 & 1.00 \\
VG2 & 7 & 0.57 & 1.52 & 3.43 & 0.88 \\
VG3 & 2 & 0.93 & 2.00 & 4.50 & 1.11 \\
VG4 & 12 & 1.01 & 2.41 & 3.17 & 1.58 \\
VG5 & 40 & 0.39 & 1.19 & 3.25 & 1.54 \\
VG6 & 13 & 0.81 & 1.79 & 3.92 & 1.27 \\
VG7 & 5 & 0.82 & 2.13 & 4.80 & 0.83 \\
VG8 & 5 & 1.36 & 3.23 & 5.80 & 0.86 \\
VG9 & 2 & 1.76 & 5.91 & 10.00 & 0.70 \\
VG10 & 5 & 1.68 & 5.16 & 9.20 & 0.76 \\
VG11 & 6 & 1.80 & 5.33 & 9.17 & 0.98 \\
VG12 & 3 & 1.79 & 5.90 & 11.00 & 0.73 \\
\hline & & & & &
\end{tabular}

Temporal variation in the diversity of the native flora

The long-term temporal changes in the dominance of $V$. cuspidata compared to native species in our study area during two censuses: 2003 and 2017 are shown in Fig. 5. The recorded mean cover percentages of $V$. cuspidata in 2017 (the present study) were 48.6, 40.9, and $26.6 \%$ in Bin El-Bahrin, Warraq and Qanater sites, respectively. In contrast, these percentages were significantly lower at the same sites in 2003 (8.2, 9.1 and 5.0 , respectively). It is obvious that there is remarkable reduction in the cover of the associated species meanwhile a distinct increase in the cover of $V$. cuspidata during 2017 compared to 2003. Regardless the number of the sampled stands in the present study and the previous studies at the same sites, the total numbers of recorded native species in 2003 were 110, 70 and 109 in Qanater, Warak and Bin El-Bahrin, respectively. On the contrary, in 2017, these numbers were declined to 34,28 , and 32 , respectively.

It is apparent that the invasion of $V$. cuspidate resulted in presence of many native species in low cover \% (e.g., Persicaria spp., Rorripa paulistris, Homognaphalium luteo-album, Eclipta alba, Eicchhornia crassipes, Cuperus aleopecroides, C. articulates). It is worth noting that in 2003, Persicaria senegalensis and E. crassipes were dominant in open water sites (personal observation), while Phragmites australis and $P$. senegalensis were the dominant in water edges and slopes. On the contrary, in 2017, V. cuspidata with or without $P$. australis was the dominant species. The similarity index between the species compositions in the study area ranged from 0.22 at Qanater to 0.55 at Waraq. The correlation coefficient between the species composition during the two censuses was low $(r=0.32)$ at Bin El-Bahrin and Qanater sites, while it was relatively high $(r=0.69)$ at Waraq island regardless the number of sampled sites at the same habitats.
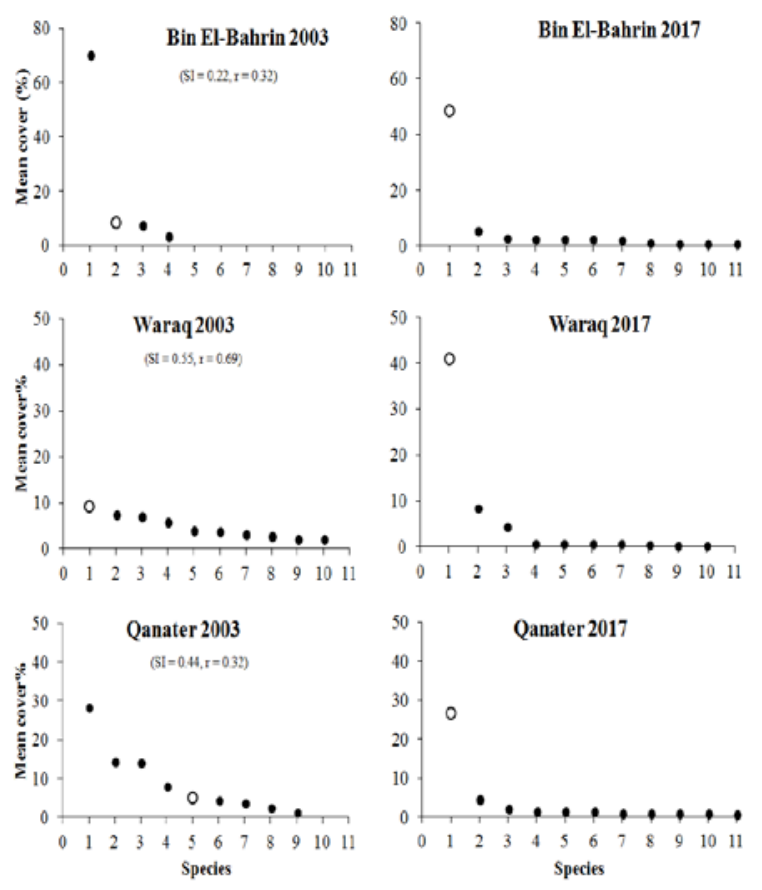

Fig. 5. Temporal changes in the cover percentage of $V$. cuspidata at the studied sites compared to the most common native associated species in 2003 and 2017. SI = Sörensen index, $r=$ correlation coefficient, hollow circle $=$ mean cover $\%$ of $V$. cuspidata, solid circle $=$ mean cover\% of most common associated species. 


\section{Soil and water characteristics}

Soil characteristics of the twelve vegetation groups in the study area are summarized in Table 3. There were only significant differences at $\mathrm{p}<0.05$ between the different vegetation groups in their contents of coarse sand and Mn. The mean values for soil $\mathrm{pH}, \mathrm{EC}\left(\mathrm{dSm}^{-1}\right)$, and sulphates (ppm) were 7.4 , 13.2 and 57.2, respectively. Soils of $P$. senegalensis- $P$. australis (VG.1), $V$. cuspidata- $P$. senegalensis (VG.7) and $B$. pilosa-A. leptophyllum (VG.12) had high values of EC (20.2 dS m $\left.{ }^{-1}\right)$, nitrogen (121.3 mg $\mathrm{l}^{-1}$ ), potassium (248.2 $\left.\mathrm{mg} \mathrm{l}^{-1}\right)$, calcium $(53.5 \mathrm{ml}$ $\mathrm{l}^{-1}$ ), magnesium (31.7 $\left.\mathrm{ml} \mathrm{l}^{-1}\right)$, sodium $(64.8 \mathrm{ml}$ $\left.\mathrm{l}^{-1}\right)$, bicarbonate $\left(5.2 \mathrm{ml} \mathrm{l}^{-1}\right)$ and chlorides $\left(100.1 \mathrm{ml} \mathrm{l}^{-1}\right)$. In contrast, they had the lowest values of fine sand (43.3 g) and silt (32.1 g). Soil of $P$. australis- $V$. cuspidata (VG.3), $V$. cuspidata-C. demersum (VG.6) and $C$. dactylon- $V$. cuspidata (VG. 9) had the highest values of fine sand (44.4 g), silt (34.4 g) and $\mathrm{pH}$ (7.5), and the lowest values of clay (3.8 g), EC (6.6 dS m$\left.{ }^{-1}\right)$, nitrogen (105.8 $\mathrm{mg} \mathrm{l}^{-1}$ ), potassium (221.9 $\mathrm{mg} \mathrm{l}^{-1}$ ) and sulphate (34.6 ml $\left.\mathrm{l}^{-1}\right)$. The soil of $R$. dentatus-C. dactylon (VG.10) showed the highest content of sulphate (79.8 $\mathrm{ml} \mathrm{kg}^{-1}$ ).

Water samples that were collected from open water and/or water edges (vegetation groups 4, 5, 8 and 10) had the highest EC, total soluble salts, magnesium, sodium, potassium, bicarbonate, chloride, and sulphate (Table 4). Meanwhile, water of the vegetation groups 6 and 9 had the highest contents of nitrate $\left(9.35 \mathrm{mg} \mathrm{l}^{-1}\right)$ and phosphorus (1.16 $\mathrm{mg} \mathrm{l}^{-1}$ ). In general, the mean values for water $\mathrm{pH}, \mathrm{EC}$. $\left(\mathrm{dSm}^{-1}\right)$, and total soluble salts were $7.43,0.38$ and 245.7, respectively.

\section{Soil and water-vegetation relationships}

The correlation between the TWINSPAN twelve vegetation groups and environmental variables (soil and water) was demonstrated by CCA biplot (Fig. 6A \& B). The soilvegetation groups $\left(\mathrm{VG}_{\mathrm{s}}\right)$ correlations were higher for the first two axes, explaining $72.7 \%$ of the cumulative variance (Fig. 6A, Table 5). It can be noticed that axis 1 was negatively correlated with $\mathrm{Mg}(\mathrm{r}=-0.251)$ and positively correlated with $\mathrm{SO}_{4}(\mathrm{r}=0.269)$. The second axis was negatively correlated with fine sand (FS) $(r=-0.676)$ and positively correlated with clay soil contents $(\mathrm{r}=0.698)$. The Monte Carlo permutation test for the first canonical axis indicated that the F-ratio (1.774) for the eigenvalue of axis $1(0.704)$ and the trace statistic to be non-significant ( $p=0.206)$. It can be noted that VG 1 and 12 are affected by many soil variables such as $\mathrm{Mg}, \mathrm{Ca}$, and $\mathrm{N}$, and occupied the upper left side of the ordination plane. On the opposite side, VG 2, 3, 4, 5, 6 and 9 are slightly affected by the soil fine sand. On the other hand, VG 8 was slightly affected by silt, while VG 10 and 11 were not affected by any of soil variables. It is worth noting that none of the estimated water variables had any significant effect on the vegetation groups in water and water edges (Fig. 6B).

Table (3): Soil characteristics of the 12 vegetation groups generated after the application of TWINSPAN. F-value is indicated, Sig = significance level

\begin{tabular}{|c|c|c|c|c|c|c|c|c|c|c|c|c|c|c|c|c|}
\hline \multicolumn{2}{|c|}{ Group } & G1 & G2 & G3 & G4 & G5 & G6 & G7 & G8 & G9 & G10 & G11 & G12 & Mean & $\begin{array}{c}\text { F- } \\
\text { value }\end{array}$ & Sig \\
\hline $\begin{array}{l}\text { Coarse } \\
\text { sand }\end{array}$ & \multirow{4}{*}{$\%$} & 20.6 & 19.0 & 17.4 & 19.0 & 19.0 & 17.4 & 20.6 & 19.0 & 17.4 & 18.3 & 17.0 & 20.6 & $18.7 \pm 1.3$ & 2.5 & 0.02 \\
\hline $\begin{array}{l}\text { Fine } \\
\text { Sand }\end{array}$ & & 43.3 & 43.9 & 44.4 & 43.9 & 43.9 & 44.4 & 43.3 & 43.9 & 44.4 & 43.8 & 44.0 & 43.3 & $43.9 \pm 0.4$ & 0.4 & 0.95 \\
\hline Silt & & 32.1 & 33.2 & 34.4 & 33.2 & 33.2 & 34.4 & 32.1 & 33.2 & 34.4 & 34.1 & 34.5 & 32.1 & $33.4 \pm 1.0$ & 1.5 & $0.1 \mathrm{C}$ \\
\hline Clay & & 4.0 & 3.9 & 3.8 & 3.9 & 3.9 & 3.8 & 4.0 & 3.9 & 3.8 & 3.9 & 3.9 & 4.0 & $3.9 \pm 0.1$ & 1.3 & 0.24 \\
\hline \multicolumn{2}{|l|}{$\mathrm{pH}$} & 7.4 & 7.4 & 7.5 & 7.4 & 7.4 & 7.5 & 7.4 & 7.4 & 7.5 & 7.5 & 7.4 & 7.4 & $7.4 \pm 0.0$ & 1.1 & $0.4 \mathrm{C}$ \\
\hline \multicolumn{2}{|c|}{$\mathrm{EC}\left(\mathrm{dS} \mathrm{m}^{-1}\right)$} & 20.2 & 13.4 & 6.6 & 13.4 & 13.4 & 6.6 & 20.2 & 13.4 & 6.6 & 17.9 & 6.6 & 20.2 & $13.2 \pm 5.6$ & 0.6 & $0.8 z$ \\
\hline
\end{tabular}


Impact of the invasive species Vossia cuspidata

\begin{tabular}{|c|c|c|c|c|c|c|c|c|c|c|c|c|c|c|c|c|}
\hline \multicolumn{17}{|c|}{ Table (3) to be continued } \\
\hline \multicolumn{2}{|c|}{ Group } & G1 & G2 & G3 & G4 & G5 & G6 & G7 & G8 & G9 & G10 & G11 & G12 & Mean & $\begin{array}{c}\text { F- } \\
\text { value }\end{array}$ & Sig. \\
\hline $\mathrm{N}$ & \multirow{5}{*}{ 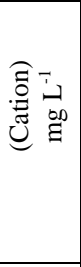 } & 121.3 & 113.5 & 105.8 & 113.5 & 113.5 & 105.8 & 121.3 & 113.5 & 105.8 & 108.9 & 103.5 & 121.3 & $112.3 \pm 6.5$ & 0.5 & 0.90 \\
\hline $\mathrm{Ca}$ & & 53.5 & 40.8 & 28.0 & 40.8 & 40.8 & 28.0 & 53.5 & 40.8 & 28.0 & 31.0 & 28.0 & 53.5 & $38.9 \pm 10.4$ & 0.5 & 0.93 \\
\hline $\mathrm{Mg}$ & & 31.7 & 22.1 & 12.6 & 22.1 & 22.1 & 12.6 & 31.7 & 22.1 & 12.6 & 13.9 & 12.5 & 31.7 & $20.6 \pm 7.9$ & 0.6 & 0.80 \\
\hline $\mathrm{Na}$ & & 64.8 & 42.9 & 21.0 & 42.9 & 42.9 & 21.0 & 64.8 & 42.9 & 21.0 & 41.5 & 21.0 & 64.8 & $40.9 \pm 17.4$ & 0.5 & 0.89 \\
\hline K & & 248.2 & 235.0 & 221.9 & 235.0 & 235.0 & 221.9 & 248.2 & 235.0 & 221.9 & 222.7 & 215.8 & 248.2 & $232.4 \pm 11.6$ & 1.1 & 0.43 \\
\hline $\mathrm{HCO}_{3}$ & \multirow{3}{*}{ 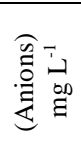 } & 5.2 & 4.8 & 4.4 & 4.8 & 4.8 & 4.4 & 5.2 & 4.8 & 4.4 & 5.2 & 4.4 & 5.2 & $4.8 \pm 0.3$ & 1.6 & 0.13 \\
\hline $\mathrm{Cl}$ & & 100.1 & 62.4 & 24.6 & 62.4 & 62.4 & 24.6 & 100.1 & 62.4 & 24.6 & 63.6 & 24.9 & 100.1 & $59.3 \pm 29.9$ & 0.6 & 0.78 \\
\hline $\mathrm{SO}_{4}$ & & 77.8 & 56.2 & 34.6 & 56.2 & 56.2 & 34.6 & 77.8 & 56.2 & 34.6 & 79.8 & 44.6 & 77.8 & $57.2 \pm 17.8$ & 0.5 & 0.87 \\
\hline \multicolumn{2}{|c|}{$\begin{array}{l}\text { Organic Matter } \\
(\%)\end{array}$} & 0.5 & 0.4 & 0.3 & 0.4 & 0.4 & 0.3 & 0.5 & 0.4 & 0.3 & 0.5 & 0.4 & 0.5 & $0.4 \pm 0.1$ & 0.6 & 0.83 \\
\hline
\end{tabular}

Table (4): Water characteristics of the vegetation groups were generated after the application of TWINSPAN and only represent water edge or open water habitats. SD: standard deviation, F-value, and significance level are indicated.

\begin{tabular}{|c|c|c|c|c|c|c|c|c|c|c|c|}
\hline \multicolumn{2}{|c|}{ Group } & G4 & G5 & G6 & G8 & G9 & G10 & Mean & SD & $\begin{array}{c}\mathrm{F}- \\
\text { value }\end{array}$ & Sig. \\
\hline \multicolumn{2}{|l|}{$\mathrm{pH}$} & 7.43 & 7.43 & 7.43 & 7.43 & 7.43 & 7.43 & 7.43 & 0.002 & 0.03 & 1.00 \\
\hline \multicolumn{2}{|c|}{$\mathrm{EC}\left(\mathrm{dS} \mathrm{m}^{-1}\right)$} & 0.39 & 0.39 & 0.38 & 0.39 & 0.38 & 0.39 & 0.38 & 0.007 & 0.07 & 1.00 \\
\hline \multicolumn{2}{|c|}{$\begin{array}{l}\text { Total soluble } \\
\text { salts (ppm) }\end{array}$} & 248.75 & 248.75 & 239.50 & 248.75 & 239.50 & 248.75 & 245.67 & 4.360 & 0.08 & 1.00 \\
\hline $\mathrm{NH}_{4}^{+}$ & \multirow{6}{*}{ 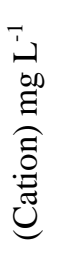 } & 2.15 & 2.15 & 2.13 & 2.15 & 2.13 & 2.15 & 2.14 & 0.013 & 0.04 & 1.00 \\
\hline $\mathrm{NO}_{3}^{-}$ & & 8.71 & 8.71 & 9.35 & 8.71 & 9.35 & 8.71 & 8.93 & 0.303 & 0.48 & 0.79 \\
\hline $\mathrm{Ca}$ & & 1.23 & 1.23 & 1.20 & 1.23 & 1.20 & 1.23 & 1.22 & 0.012 & 0.04 & 1.00 \\
\hline Mg & & 1.90 & 1.90 & 1.74 & 1.90 & 1.74 & 1.90 & 1.84 & 0.072 & 0.23 & 0.95 \\
\hline $\mathrm{Na}$ & & 1.49 & 1.49 & 1.38 & 1.49 & 1.38 & 1.49 & 1.45 & 0.051 & 0.13 & 0.98 \\
\hline K & & 0.16 & 0.16 & 0.10 & 0.16 & 0.10 & 0.16 & 0.14 & 0.026 & 0.42 & 0.83 \\
\hline $\mathrm{HCO}_{3}$ & \multirow{3}{*}{ 施 } & 1.18 & 1.18 & 1.14 & 1.18 & 1.14 & 1.18 & 1.17 & 0.017 & 0.05 & 1.00 \\
\hline $\mathrm{Cl}$ & & 1.25 & 1.25 & 1.16 & 1.25 & 1.16 & 1.25 & 1.22 & 0.040 & 0.27 & 0.93 \\
\hline $\mathrm{SO}_{4}$ & & 2.28 & 2.28 & 2.12 & 2.28 & 2.12 & 2.28 & 2.23 & 0.073 & 0.12 & 0.99 \\
\hline \multicolumn{2}{|c|}{$\begin{array}{l}\text { Saturated Na } \\
\text { Ratio }\end{array}$} & 1.17 & 1.17 & 1.10 & 1.17 & 1.10 & 1.17 & 1.15 & 0.036 & 0.19 & 0.96 \\
\hline
\end{tabular}




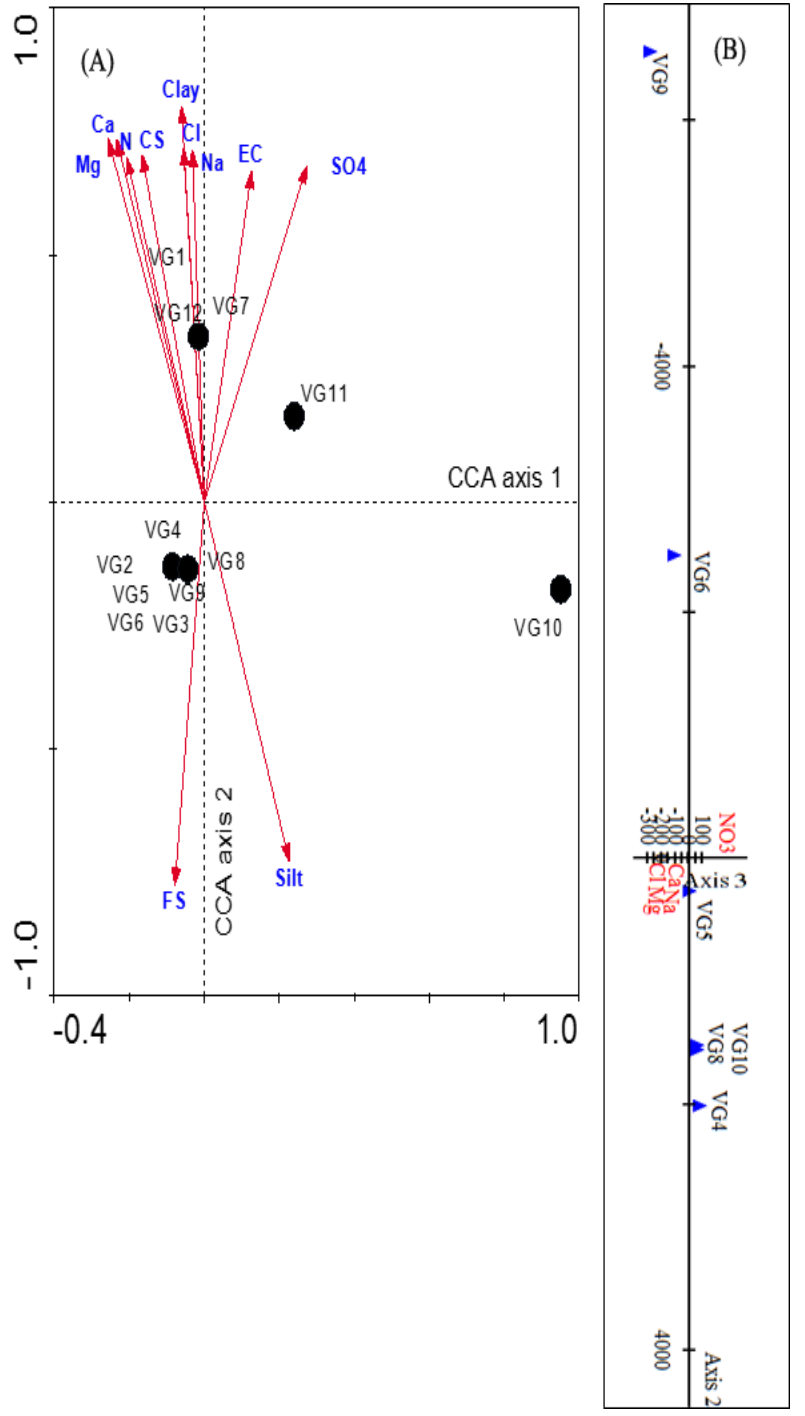

Figure (6) CCA ordination biplot indicating the relationship between the 12 vegetation groups, generated after application of TWINSPAN, and soil (A) and water variables (B). Variables are represented by lines. $\mathrm{EC}=$ Electrical Conductivity, $\mathrm{CS}=$ coarse sand, $\mathrm{FS}=$ fine sand.

\section{Discussion}

Identification and description of the plant communities and their relation to the environment is an important step in understanding the vegetation structure of the studied aquatic and riparian habitats. It represents an important component of any effective conservation planning (Brown et al. 2013; Al Harthy and Grenyera 2019). In of the
Table 5. Inter-set correlation of CCA analysis for the soil/sediment variables, together with eigenvalues and speciesenvironment relations

\begin{tabular}{lcc}
\hline \multirow{2}{*}{ Environmental variables } & \multicolumn{2}{c}{ CCA axes } \\
\cline { 2 - 3 } & $\mathbf{1}$ & $\mathbf{2}$ \\
\hline $\begin{array}{l}\text { Eigenvalues } \\
\text { Species-environment } \\
\text { correlations }\end{array}$ & 0.704 & 0.378 \\
Cumulative percentage variance & & \\
of species-environment relation & 47.3 & 72.7 \\
& & \\
Electrical conductivity (EC) & 0.1248 & 0.584 \\
N & -0.203 & 0.6079 \\
Ca & -0.229 & 0.6402 \\
Mg & -0.251 & 0.6402 \\
Na & -0.054 & 0.625 \\
Cl & -0.031 & 0.6216 \\
SO4 & 0.2698 & 0.5928 \\
Coarse soil (CS) & -0.163 & 0.6128 \\
Fine soil (FS) & -0.077 & -0.676 \\
Silt & 0.2233 & -0.634 \\
Clay & -0.06 & 0.6981 \\
\hline
\end{tabular}

addition, to get a clear picture of the influence of environmental factors on the spatial distribution of vegetation communities is an important step to to predict the future response of vegetation to environmental factors (Rahman et al. 2020). Studying the impacts of invasive plants on the community level in situ by investigating either the species composition stands during different time intervals and/or comparing invaded and uninvaded stands provide valuable information for nature conservation and landscape management (Manchester and Bullock 2000). Vossia cuspidata has not been included in any Flora or checklist in Egypt before Bolous (1995). It was recorded in some ecological studies in the River Nile in Egypt, including, Shehata (1996) in the south and middle Nile Delta, Shaltout and Al-Sodany (2000) in Lake Burullus at north Nile Delta, Farahat 
(2006) in the south Nile Delta and Shaltout et al. (2010).

In the present study, the plant species which associated with $V$. cuspidata belonging to 28 families of angiosperms, and they represented $17 \%$ of the Egyptian flora and about $16 \%$ of the naturalized freshwater species. The largest percentage of species belong to Poaceae, followed by Astraceae (about $12 \%$ ). Many plants belonging to Poaceae are important pasture crops on which livestock production is dependent (Cook and Dias 2006). The species of both Poaceae and Astraceae have the ability for rapid growth and extensive spread (Papes and Peterson 2003; Michelan et al. 2010).

In this study, the life-form spectrum is characteristic of an aquatic region with the dominance of therophytes (51\% of the total recorded species). Terraces and slopes had the highest number of the therophytes. Previous studies indicated that therophytes are not adapted to grow in the water surface as they inherently cannot develop subterranean perennating organs as in the case of perennial sedges and rushes (Al-Sodany 1998). Nanophanerophytes, chaemophytes and geophytes were well represented along the slopes and water edges. Slopes can be considered as transitional habitats between terrace and water edge due to the fluctuation of water levels in watercourses. Such sites are considered as favorable habitats, which support the growth of many species. The helophytes are adapted to grow in water edges and open water more than in other habitats (Farahat 2006). This is due to their life forms, as they produce perennating organs, which resist the disturbances created by the actions of water currents in the shoreline and in the riparian zones and due to the water requirements of such species. This agrees with many authors who studied the aquatic and riparian vegetation in the Nile Delta (e.g., AlSodany 1992 and 1998; Shaltout and ElHalawany 1993 and El-Sheikh 1996).

The present study revealed that $V$. cuspidata was the most dominant species among the recorded plants and form dominant dense cover on the banks of the River Nile. In many sites, the extensive growth of $V$. cuspidata in the open water was found intermingled with the masses of the water hyacinth (Eichhornia crassipes), and together they formed dense mats of vegetation. We think that pattern is one of the main strategies by which $V$. cuspidata competes with most of the native species in the present study, particularly short species. Hejda et al. (2009) reported that tall invading species can form populations with greater cover than that of native dominant species, which lead to a remarkable decrease in species diversity and evenness. Since the target species has never been known to flower in Egypt (Boulos 2005), it is concluded that its spread from the tropical Africa to the Northern regions of the River Nile systems in Egypt is likely based on vegetative reproduction. Vegetative reproduction of this species may be one of its advantages over other species that it could outcompete. This way of dispersion is like that reported for other successive invasive and cosmopolitan species e.g., $P$. australis and $E$. crassipes. In addition, $V$. cuspidata has floating rhizomes that enable it to grow and spread in strongly flowing waters (Thompson 1985). Heidbüchel et al. (2016) indicated that the rhizomes and the stem fragments of aquatic plants are the most important units of vegetative reproduction and dispersal. Another factor that could help in spreading of this species in Egypt is that the local fishermen in the study area fix it in open water and some water edges to hide their traps beneath its branches (personal observation). Meanwhile, they remove some of the native plants for this purpose (e.g., P. senegalensis). Consequently, a gradual decline in the richness of the native species takes place.

According to the TWINSPAN technique, twelve vegetation groups were generated and named after their dominant and co-dominant species. It is noticed that $B$. pilosa - A. leptophyllum (VG.12) and R. dentatus - C. dactylon (VG.10) were characterized with short plants that could not compete with $V$. cuspidata and had high richness value. On the 


\section{Waleed F. Mahmoud et al.}

contrary, V. cuspidata- I. carnea (VG.2), P. australis-V. cuspidata (VG.3 and 4) were characterized by tall plants that prevent the light penetration to the associated species and therefore, there would be no available gaps for any other species to grow between their branches.

The variations in species richness and evenness among the different habitat types may not only attributed to soil and water characteristics, but possibly to human disturbance and other plant-plant interactions (e.g., allelopathy and competition) (Adebayo et al. 2011). In the present study, the variations in species diversity appear to be related to the environmental variables in the different habitats. The lowest values of species diversity, which were recorded in the open water habitat may be due to water velocity, water pollution and weed control. The lowest values of diversity indices were found in the plant communities in the open water, were represented by vegetation groups 5, 6 and 8 . In the study area, there were fluctuations in water level among seasons and frequent control to aquatic plants in open water, which reduces the species richness in this habitat. The same results were reported by Al-Sodany (1998) who reported a low diversity of aquatic plants in the River Nile in Egypt. On the other hand, the highest values of diversity which were recorded in the water edges and slopes may be attributed to the limited changes in the habitat conditions in these environments compared to open water. This is in line with the reported findings by many investigators (e.g., Hegazy et al. 1994; El-Khatib et al. 2004 and James et al. 2006).

Comparison of the mean cover percentage of $V$. cuspidata in the present study with previous studies in the same area, revealed that the prevalence of $V$. cuspidata has increased five times during the last fifteen years compared to other native species such as $P$. salicifolia, P. lapathifolia, P. salicifolia, Homognaphalum luteo-album and Rorripa paulistris in terraces, slopes and water edges. As well, $V$. cuspidata replaced $P$. senegalensis,
P. lanigera, L. stolonifera and E. crassipes in open water in many sites or at least reduced the cover of these species to the minimum (Personal observation). Consequently, this drastic change in the native flora will alter the ecosystem functions and services that were prevailed before the invasion by $V$. cuspidata. In addition, some native species (mainly Persicaria spp.) are now scarcely observed along the River Nile (personal observation). With this strong impact on the community scale, $V$. cuspidata represents a serious hazard to the ecosystem and native flora need urgent conservation.

Soil and water characteristics of the vegetation groups did not show high significant variability for most of the analyzed variables among the produced vegetation communities. This could simply be attributed to the fact that the three studied sites are located at two sedimentary Nile islands with the same biotic and abiotic conditions.

The vegetation-environment relationship when assessed by CCA indicated the relative positions of vegetation groups and sites along the most important ecological gradients. The analysis indicated that $\mathrm{Mg}, \mathrm{SO}_{4}$, fine sand and clay are the most important soil variables that control the distribution of the plant species in the study area. It can be inferred that CCA axis 1 is negatively correlated with magnesium and positively with $\mathrm{SO}_{4}$, so this axis can be interpreted as magnesium-sulphate gradient, while the second axis is defined by fine sand and clay. This was reported in other studies which were carried out in the aquatic habitats of the River Nile e.g., El-Demerdash et al. (1997); ElHalawany (2000).

\section{Conclusion}

The present study documented the changes in the vegetation structure in the River Nile ecosystem due to the invasion by $V$. cuspidata. It indicated the dominance of $V$. cuspidata in most of the investigated habitats in the study area. Its dominance resulted in the reduction of the species richness and evenness of most of the native species in riparian and aquatic 
habitats. The plant height, its cover, vegetative reproduction, and anthropogenic factors facilitated the dispersion of $V$. cuspidata in the River Nile system and its replacement to the native flora. Moreover, recording of $V$. cuspidata in the studied four habitats reflects its ability to adapt to the habitat heterogeneity of the River Nile ecosystem (i.e., dry and wet habitats). This provides the species with an extra advantage over the other associated species, which are confined to one or two habitats only, according to its water demands and its adaptability to the site conditions. It was found that magnesium sulphate, fine sand and clay were the main abiotic factors that correlated with the vegetation communities of the species. We can conclude that $V$. cuspidata represents a serious problem to the structure and function of the River Nile ecosystem. The impact of $V$. cuspidata on the other ecosystem functions and services (e.g., soil water content, soil nutrients, water current flow, light intensity, etc.) have not yet studied and need further investigation. We think that this study will attract the attention of stakeholders for the wildlife along the River Nile in African countries and it will enhance them to manage this invasive grass to reduce it negative impacts on the native species.

\section{Acknowledgements}

Many thanks to the anonymous reviewers and the Editor-in-Chief for their valuable suggestions and comments that improved the manuscript. We thank Prof. Monier Abdel Ghani for his kind help in CCA and its explanation.

\section{References}

Adebayo, A.A., Briski, E., Kalaci, O., Hernandez, M., Ghabooli, S., Beric, B., Chan, F.T., Zhan, A., Fifield, E., Leadley, T. and MacIsaac, H.J. 2011. Water hyacinth (Eichhornia crassipes) and water lettuce (Pistia stratiotes) in the Great Lakes: playing with fire? Aquat Invasions 6(1): 91-96
Al Harthy, L. and Grenyera, R. 2019. Classification and ordination of the main plant communities of the Eastern Hajar Mountains, Oman. J Arid Environ.169:1-18.

Allen, T. 1990. Particle size measurement. Volume 1: Powder sampling and particle size measurement. Chapman \& Hall, London, UK. Al-Sodany, Y.M. 1992. Vegetation analysis of the northern part of Nile Delta region. M.Sc. Thesis, Tanta University, Egypt

Al-Sodany, Y.M. 1998. Vegetation analysis of the canals, drains and lakes of the northern part of Nile Delta. Ph.D. Thesis, Tanta University

Black, C.A. 1982. Methods of soil analysis. Part 2. Chemical and microbiological properties. Second Edition. Amer Soc. Of Agron. Madison, Wisconsin, USA

Blackburn, T.M. 2014. Unified classification of alien species based on the magnitude of their environmental impacts. PLOS Biology 12: (art. e1001850)

Blackburn, T.M., Pysek, P., Bacher, S. et al. 2011. A proposed unified framework for biological invasions. Trends Ecol Evol 26: 333-339

Boulos, L. 1995. Flora of Egypt: Checklist. Al Hadara Publishing, Cairo, Egypt. pp. 287

Boulos, L. 1999. Flora of Egypt: vol.1 (Azollaceae - Oxalidaceae). Al Hadara Publishing, Cairo, Egypt, pp. 419

Boulos, L. 2000. Flora of Egypt: vol. 2 (Geraniaceae - Boraginaceae). Al Hadara Publishing, Cairo, Egypt, pp. 352

Boulos, L. 2005. Flora of Egypt: vol. 4 (Alismataceae - Orchidaceae). Al Hadara Publishing, Cairo, Egypt, pp. 617

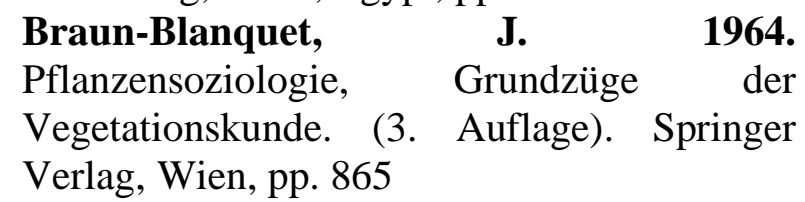

Brown, L.R., Preez, D.U., Bezuidenhout, P.J., Bredenkamp, H., Mostert, G.J. and Collins, N.B. 2013. Guidelines for phytosociological classifications and descriptions of vegetation in southern Africa. Koedoe 55(1): 1-10

Castro-Díaz, P., Godoy, O., Alonso, A., Gallardo, A. and Saldana, A. 2014. What explains variation in the impacts of exotic 
plant invasions on the nitrogen cycle? A metaanalysis. Ecol Letters 17: 1-12

Chapman, H.D. and Pratt, R.E. 1961. Methods of Analysis for Soil, Plants and Water. Dept. of Soil, Plant Nutrition, Univ. of California, USA, pp. 309.

Cook, G.D. and Dias, L. 2006. It was no accident: deliberate plant introductions by Australian government agencies during the 20th century. Aust J Bot 54: 601-625

Dostál, P., Dawson, W., Van Kleunen, M., Keser, L.H. and Fischer, M. 2013. Central European plant species from more productive habitats are more invasive at a global scale. Global Ecol. Biogeogr. 22: 64-72

Eid, E.M. 2002. Population ecology of Ipomoea carnea Jacq. in the Nile Delta region. M.Sc. Thesis, Tanta University, Tanta, Egypt El-Demerdash, M.A., Hosni, H.A. and AlAshri, N. 1997. Distribution of weed communities in the northeast of Nile Delta, Egypt. Feddes Repertorium 108: 219-232

El-Halawany, E.F. 2000. Flora and vegetation of date palm orchards in the Nile Delta, Egypt. Proceedings of the 1stInternational Conference on Biological Sciences, Faculty of Science, Tanta University, Tanta 1: 266-283 El-Khatib, A.A., Hegazy, A.K. and Galal, H.K. (2004) Allelopathy in the rhizosphere and amended soil of Chenopodium murale L. Weed Biol Mana. 4: 35-42

El-Sheikh, M.A. 1996. Ruderal plant communities of the Nile Delta region. Ph.D. Thesis, Tanta University, Egypt

Farahat, E.A. 2006. Vegetation-environment relationships in the south Nile Delta. Ph.D. Thesis. Faculty of Science, Helwan University, Egypt. pp 221

Galal, T.M. 2001. Studies on the River Nile

Vegetation in El Kahira El Kobra. MSc.

Thesis, Faculty of Science, Helwan

University.

Galal, T.M., Gharib, F.A., Ghazi, S.G. and Mansour, K.H. 2017. Phytostabilization of heavy metals by the emergent macrophyte Vossia cuspidata (Roxb.) Griff.: a phytoremediation approach, Int J Phytoremediat 19(11): 992-999

Galatowitsch, S.M., Anderson, N.O. and Ascher, P.D. 1999. Invasiveness in wetland plants in temperate North America. Wetlands 19: 733-755.

Hegazy, A.K., Diekmann, M. and Ayad, G. 1999. Impact of plant invasions on ecosystems and native gene pools. In: Environment 2000 and Beyond. pp. 275-310

Hegazy, A.K., Soliman, M.I. and Mashaly, I.A. 1994. Perspectives on the Biology of Heliotropium curassavicum in the Deltaic Mediterranean Coast of Egypt. Arab Gulf J Sci Res 12: 525-545

Heidbüchel, P., Kuntz, K. and Hussner, A. 2016. Alien aquatic plants do not have higher fragmentation rates than native species: a field study from the River Erft. Aquat Sci 78: 767-777

Hejda, M., Pyšek, P. and Jarošík, V. 2009. Impact of invasive plants on the species richness, diversity and composition of invaded communities. J. Ecol. 97: 393-403

Hill, M.O. 1979a. DECORANA-A FORTRAN program for detrended correspondence analysis and reciprocal averaging. Cornell University, Ithaca N.Y. pp. 90

Hill, M.O. 1979b. TWINSPAN - A FORTRAN program for arranging multivariate data in an ordered two-way table by classification of the individuals and attributes. Cornell University, Ithaca. N.Y. pp. 52

James, J.J., Caird, M.A., Drenovsky, R.E. and Sheley, R.L. 2006. Influence of resource pulses and perennial neighbors on the establishment of an invasive annual grass in the Mojave Desert. J Arid Environ 67: 528534

Koerner, S.E., Avolio, M.L., Chang, C.C., Gray, J., Hoover, D.L. and Smith, M.D. 2015. Invasibility of a mesic grassland depends on the time-scale of fluctuating resources. J Ecol 103: 1538-1546

Kumschick S, Gaertner M, Vila` M, Essl F, Jeschke JM, Pyšek P, Ricciardi A, Bacher S, Blackburn TM, Dick JTA, Evans T, Hulme PE, Kühn I, Mrugala A, Pergl J, Rabitsch W, Richardson DM, Sendek $A$ and Winter M. (2015) Ecological impacts of alien species: quantification, scope, caveats, and recommendations. BioScience 65: 55-63 
Leps $J$ and Šmilauer P. (2003) Multivariate Analysis of Ecological Data using CANOCO. Cambridge University Press, UK, pp. 269.

Magurran, A.E. 1988. Ecological Diversity and its Measurements. Princeton University Press. Princeton, New Jersy, pp. 179

Manchester, S.J. and Bullock, J.M. 2000. The impacts of non-native species on UK biodiversity and the effectiveness of control. $\mathrm{J}$ Appl Ecol 37: 845-864

Markus, D.K., Mckinnon, J.P. and Buccafuri, A.F. 1982. Automated Analysis of Nitrite, Nitrite and ammonium Nitrogen in soils. New Jersey Agric. Exp. Stn. 9(5), pp.1208-1215.

Michelan, T.S., Thomaz, S.M., Carvalho, P., Rodrigues, R.B. and Silveira, A.J. 2010. Regeneration and colonization of an invasive macrophyte grass in response to desiccation. Nat Conserv 20: 133-139

Papes, M. and Peterson, A.T. 2003. Predicting the potential invasive distribution for Ageratina adenophora in China. J Wuhan Bot Re 21: 137-142

Pfisterer, A.B., Joshi, J., Schmid, B. and Fischer, M. 2004. Rapid decay of diversityproductivity relationships after invasion of experimental plant communities. Basic Appl Ecol 5: 5-14

Pielou, E.C. 1975. Ecological Diversity. A Willy-Interscience Publication, New York, pp.165

Pyšek, P., Jarošík, V., Hulme, P.E., Perg, l.J., Hejda, M., Schaffner, U. and Vilà, M. 2012. A global assessment of invasive plant impacts on resident species, communities, and ecosystems: The interaction of impact measures, invading species' traits and environment. Global Change Biol 18: 17251737

Pyšek, P., Richardson, D.M., Rejmánek, M., Webster, G., Williamson, $M$. and Kirschner, J. 2004. Alien plants in checklists and floras: towards better communication between taxonomists and ecologists. Taxon 53: 131-143

Rahman, I.U., Khan, N., Ali, K. and Ahmad, S. 2020. Vegetation-environment relationship in Pinus wallichiana forests of the Swat
Hindukush range of Pakistan. J For Res 31(1): 185-195

Raphael E., Momoh S., Kayode, D., Gideon, A. and Friday, E.T. 2016. The phytochemical constituents of Vossia cuspidata and Synedrella nodiflora. Int J Curr Res Biosci Plant Biol 3(8): 53-57

Richardson, D.M., Pysek, P., Rejmanek, M., Barbour, M.G., Panetta, F.D. and West, C.J. 2000. naturalization and invasion of alien plants: concepts and definitions. Divers Distrib 6: 93-107

Seebens, H., Blackburn, T.M., Dyer, E.E. et al. 2017. No saturation in the accumulation of alien species worldwide. Nat Commun 8: 14435

Seebens, H., Essl, F., Dawson, W. et al. 2015. Global trade will accelerate plant invasions in emerging economies under climate change. Global Change Biol 21: 4128-4140

Shaltout, K.H. and Al-Sodany, Y.M. 2000. Flora and vegetation of lake Burullus area. Med Wet Coast, Egyptian Environmental Affairs Agency, Cairo

Shaltout, K.H. and El-Halawany, E.F. 1993. Vegetation Analysis of the Irrigation and Drainage Canals in Eastern Saudi Arabia. J Univ Kuwait (Sci) 20: 261-273

Shaltout, K.H. and Galal, T.M. 2006. Comparative study on the plant diversity of the Egyptian northern lakes. Egypt J Aquat Res 32: 254-270

Shaltout, K.H., Sharaf El-Din, A., Ahmed, D.A. 2010. Plant life in the Nile Delta. Tanta University Press, Tanta, Egypt. pp. 232

Shehata, M.N. 1996. Ecological studies on Vossia cuspidata (Roxb.) Griff. in the Nile Delta of Egypt. Egy J Bot 36 (1): 37- 51

Smith, M.D. and Knapp, A.K. 1999. Exotic plant species in a C4-dominated grassland: invasibility, disturbance, and community structure. Oecologia 120: 605-612

Strayer, D.L., Eviner, V.T., Jeschke, J.M. and Pace, M.L. 2006. Understanding the long-term effects of species invasions. Trends Ecol Evol 21: 645-651

Täckholm, V. 1974. Students' Flora of Egypt, ( $2^{\text {nd }}$ ed.). Cairo University Press, Cairo, pp. 888 
Ter Braak, C.J.F. and Smilauer, P. 2002. CANOCO reference manual and Cano Draw for Windows user's guide: Software for Canonical Community Ordination (version 4.5). Biometris, Wageningen

Ter Braak, C.J.F. 1990. Update notes: CANOCO version 3.1. Wageningen: Agricultural Mathematics Group

Thompson, K. 1985. Emergent plants of permanent and seasonally flooded wetlands. In: Denny, P. (Editor): The ecology and management of African wetland vegetation. Dr. W. Junk Publishers, Dodrecht, Holland Thuiller, W., Gallien, L., Boulangeat, I., de
Bello, F., Munkemuller, T., Roquet, C. and Lavergne, S. 2010. Resolving Darwin's naturalization conundrum: a quest for evidence. Divers Distrib 16: 461-475

Tognetti, P.M. and Chaneton, E.J. 2015. Community disassembly and invasion of remnant native grasslands under fluctuating resource supply. J Appl Ecol 52: 119-128

van Kleunen, M., Dawson, W., Essl, F. et al. 2015. Global exchange and accumulation of non-native plants. Nature 525: 100-103

Whittaker, G.H. 1972. Evolution and Measurements of Species Diversity. Taxon 21: 213-251 


\section{Impact of the invasive species Vossia cuspidata}

Appendix: The families, life forms and chorotypes of the recorded species. COSM= Cosmopolitan, PAL= Palaeotropical, PAN=Pantropical, S-Z= Sudano-Zambezian, MED= Mediterranean, SA-SI= Saharo-Sindian, TRP= Tropical, IR-TR= Irano-Turanian, EU-SB= Euro-Siberian. A=Annual, Th=Therophytes, Hy= Hydrophytes, $\mathrm{H}=$ Hemicryptophytes, N.Ph=Nano phanerophytes, $\mathrm{Ch}=$ Chaemophytes, G= Geophytes

\begin{tabular}{|c|c|c|c|}
\hline Species Name & Family & Life Forms & Chorotype \\
\hline Alternanthera sessilis (L.) DC. & Amaranthaceae & Hy & PAN \\
\hline Cynanchum acutum L. subsp. acutum & Asclepiadaceae & N. $\mathrm{Ph}$ & MED, IR-TR, EU-SB \\
\hline Ceratophyllum demersum L. & Ceratophyllaceae & Hy & COSM \\
\hline Chenopodium ficifolium Sm. & Chenopodiaceae & Th & MED \\
\hline Chenopodium murale L. & Chenopodiaceae & Th & COSM \\
\hline Eclipta alba (L.) Hassk. & Astraceae & Th & COSM \\
\hline Pluchea dioscoridis (L.) DC. & Astraceae & N. $\mathrm{Ph}$ & SA-SI, S-Z \\
\hline Senecio aegyptius L. & Astraceae & Th & MED \\
\hline Sonchus oleraceus L. & Astraceae & Th & COSM \\
\hline Bidens pilosa $\mathrm{L}$. & Astraceae & Th & PAN \\
\hline Gnaphalium luteo-album L. & Astraceae & Th & COSM \\
\hline Ipomoea carnea Jace. & Convolvulaceae & $\mathrm{H}$ & TRP \\
\hline Coronopus niloticus (Del.) Spreng. & Brassicaceae & Th & $\mathrm{S}-\mathrm{Z}$ \\
\hline Rorippa palustris (L.) Besser & Brassicaceae & Hy & MED \\
\hline Luffa cylindrica M.Roem. & Cucurbitaceae & A & TRP \\
\hline Cyperus aleopecuroides Rottb. & Cyperaceae & Hy & PAN \\
\hline Cyperus rotundus L. & Cyperaceae & G & PAN \\
\hline Euphorbia peplus L. & Euphorbiaceae & Th & COSM \\
\hline Ricinus communis L. & Euphorbiaceae & $\mathrm{Ch}$ & PAN \\
\hline Arundo donax L. & Poaceae & N. $\mathrm{Ph}$ & PAN \\
\hline Cynodon dactylon (L.) Pers. & Poaceae & G & PAN \\
\hline Echinochloa stagnina (Retz.) P.Beauv. & Poaceae & Th & PAL \\
\hline Phragmites australis (Cav.) Trin. Ex Steud. & Poaceae & Hy & PAL \\
\hline Poa annua L. & Poaceae & Th & MED, IR-TR, EU-SB \\
\hline Setaria verticillata (L.) P. Beauv. & Poaceae & Th & COSM \\
\hline Setaria viridis (L.) Beauv. & Poaceae & Th & COSM \\
\hline Vossia cuspidata (Roxb.) Griff. & Poaceae & Hy & SA-SI, S-Z \\
\hline Myriophyllum spicatum L. & Haloragidaceae & Hy & COSM \\
\hline Melilotus indicus (L.) All. & Fabaceae & Th & PAL \\
\hline Trifolium resupinatum $\mathrm{L}$. & Fabaceae & Th & MED, IR-TR, EU-SB \\
\hline Malva parviflora L. & Malvaceae & Th & MED \\
\hline Glinus lotoides L. & Molluginaceae & Th & PAL \\
\hline Nymphaea lotus L. & Nymphaeaceae & Hy & PAL \\
\hline Ludwigia stolonifera (Guill. \& Perr.) P. H. Raven & Onagraceae & Hy & $\mathrm{S}-\mathrm{Z}$ \\
\hline Emex spinosa (L.) Campd. & Polygonaceae & Th & MED \\
\hline Persicaria lapathifolia (L.) Gray & Polygonaceae & Hy & MED \\
\hline Persicaria salicifolia (Brouss. ex Willd.) Assenov & Polygonaceae & Hy & PAL \\
\hline Persicaria senegalensis (Meisn.) Soják & Polygonaceae & Hy & $\mathrm{S}-\mathrm{Z}$ \\
\hline Rumex dentatus L. & Polygonaceae & Th & MED, IR-TR \\
\hline Eichhornia crassipes (C. Mart.) Solms & Pontenderiaceae & Hy & COSM \\
\hline Potamogeton pectinatus L. & Potamogetonaceae & Hy & COSM \\
\hline Anagallis arvensis L. & Primulaceae & Th & COSM \\
\hline Ranunculus sceleratus L. & Ranunculaceae & Hy & MED, IR-TR. EU-SB \\
\hline Potentilla supina $\mathrm{L}$. & Rosaceae & Th & $\mathrm{S}-\mathrm{Z}$ \\
\hline Veronica anagallis-aquatica $\mathrm{L}$. & Scrophulariaceaea & Hy & COSM \\
\hline Datura innoxia Mill. & Solanaceae & Th & PAN \\
\hline Solanum nigrum L. & Solanaceae & $\mathrm{Ch}$ & COSM \\
\hline Withania somnifera (L.) Dunal & Solanaceae & Ch & SA-SI, S-Z \\
\hline Typha domingensis (Pers.) Poir. ex Steud. & Typhaceae & Hy & PAN \\
\hline Apium leptophyllum (Pers.) F. Muell. ex Benth. & Apiaceae & Th & PAN \\
\hline Urtica urens L. & Urticaceae & Th & MED, IR-TR, EU-SB \\
\hline
\end{tabular}

